\title{
News from the Dutch Colony of Pella in North America, June 1854
}

\author{
EDITED BY ROBERT P. SWIERENGA
}

"America letters" from immigrants in North America always found a ready readership in Europe in the nineteenth century. Many such letters have been found and preserved in recent years, as scholars have belatedly come to realize their value for understanding the process of international emigration. The following letter was penned by an anonymous farmer in the Pella colony in 1854, some seven years after the founding of this first Dutch settlement in Iowa. The letter was addressed to a friend in the city of Utrecht in the Netherlands, a Professor J. Ackersdijck, who, realizing its general value, had it published the next year in a popular economics periodical, Tijdschrift voor Staathuishoudkunde en Statistiek [Journal for Economics and Statistics]. The editor of the journal, Baron W. A. E. Sloet tot Oldhuis, was a leading agrarian reformer who sought to encourage changes in national legal and socio-economic policies that virtually drove many peasants to emigrate overseas. This optimistic report from the Iowa farmer to his countrymen clearly demonstrated the powerful nature of that appeal and it must have served as a sober warning to government officials to initiate reforms or face a heavy loss of population.

The report describes the arduous task of turning virgin land into productive farms and the economic rewards of those who succeed. Although people had to work all year round from 7:00 a.m. to 6:00 p.m., poverty was unknown and "the poorest person spreads his table with the best of wheaten bread and bacon." The writer owned a 320acre farm and was quickly getting it into full scale grain production. He earned about ten dollars an acre on his grain crop and expected to buy a new threshing machine to increase his production.

The letter also favorably contrasts conditions in frontier Iowa with those in Holland, where agriculture was languishing and land was extremely scarce. For a Netherlander of average means to own a 
320-acre farm and expensive threshing machinery was unthinkable. The "Mr. S.", cited in the letter, who was reputedly becoming a millionaire, was the founder and leader of the Pella colony, the Reverend Mr. Hendrik Peter Scholte. He was a man with inherited wealth who had graduated from the University of Leiden. Scholte was the largest landowner in Pella, the owner and editor of the Pella Gazette, the town notary public, as well as the pastor of the leading church of the town, the Pella Christian Church. Scholte at his death in 1868 was hardly a millionaire, but he did enjoy one of the highest standards of living in frontier lowa, as any will attest who have toured his large home on the square in Pella.

This letter has been translated by Mrs. Annette Boomker Doezema of South Holland, Illinois, with the assistance of Professor Adriaan de Wit of Kent State University. The original was published in the Tijdschrift voor Staathuishoudkunde en Statistiek, 11th part, 1855, pages 365-368. The final note was added by the editor, Sloet tot Oldhuis, to lend credence to the anonymous report.

THROUGH THE GOODNESS OF THE LORD we are in excellent health; the children are growing up and the girls will become good farmers' wives. Since I have only one son, I had to call on the girls to help in doing the farm work. As a result, if need be they could easily manage a farm as well as any he-man, because they can plow, harrow, drive home the grain with horse and wagon, and plant.

Now something regarding our colonization. The first years we had to cope with many difficulties, indeed so many I did not think the colony would survive. But after 3 or 4 years, progress was so great that the Americans were astonished, especially at our clearing the land and making it tillable to such a large extent. Thus, Sir, I emphatically declare that many destitute people might wish to come here, because poverty is unknown here. The poorest person spreads his table with the best of wheaten bread and bacon. People don't have to eat rye bran-bread, neither do they have to work till exhaustion for 15 to 20 stuivers [Dutch coins equivalent to U.S. nickels]. The lowest wages for tradesmen are: $\$ 1$ for a hodman, for a bricklayer $\$ 1.25$ to $\$ 1.50$, and then not only 8 months of work as in Holland, but all year round, and the wages in winter are as high as in summer. Here men work from 7 a.m. to 6 p.m., which is possible because in 
winter the days are longer than they are in Holland. The climate is also very healthful here, but uncomfortably cold in winter. So, if you should like to visit the colony in winter, I would advise you to make sure you have plenty of winter coats and woolens.

Now something regarding my own business affairs. I have a farm of 150 morgen [ 320 acres], of which I plant 90 morgen [192 acres] with wheat, oats, corn, and mustard seed, plus a few potatoes. This year I fenced in another 33 morgen [70 acres] where I hope to break ground next year and plant wheat. This year I sowed 50 morgen [ 107 acres] with wheat and oats, 7 morgen [15 acres] with mustard seed that thrives here too, and then 30 morgen [ 64 acres] with corn for feeding the cattle this winter because here you must feed livestock [grain] for six months. I hope to slaughter 60 to 70 fat hogs this fall that I fattened myself. Bacon is higher the last two years. People earn 7 cents a pound altogether for smoked bacon, hams, shoulders and sides. Everything is much higher in price than 3 or 4 years ago. A good workhorse is $\$ 100$ to $\$ 150$, a good yoke of oxen $\$ 80$ to $\$ 100$, a good dairy cow with her calf $\$ 30$ to $\$ 40$. Horse and cattle-breeding is thus very profitable, because during the summer they cost nothing since they graze in the open field.

Thus there isn't much more we could wish for, except for some capitalists to invest part of their money here at 6 percent, which would allow many Hollanders farther up [north] to buy land from the state-which still has plenty-and to till it. The land 20 miles around and north of Pella was purchased mostly from the state. Even around Pella land is becoming expensive. I could have gotten $\$ 7,000$ for my farm, but I don't want to sell it. Contracts have been let to make the Des Moines River navigable for steamboats; a portion is already finished. Railroads are also being laid from New York at Calvanie [Albany], which are going through Pella. Your Honor possibly knows that each community may have a high school, so Pella is also building one, which is of great importance to the city. There is a good chance that Pella will become the capital city.

Concerning Mr. S [Hendrik Peter Scholte] I can write you that he most likely will become a millionaire, because he has large tracts of land for farms, the best woods belong to him, and also the city [of Pella]. In the beginning he sold lots for $\$ 50$ in the best locations, but should you want a lot with a good location now, 
you will have to pay from $\$ 200$ to $\$ 500$ for it. This fall I purchased by private contract a half lot with a neat little house on it for $\$ 300$. I could now get $\$ 500$ for it. From this you can see the progress of the town. I believe the state of Iowa is one of the most fruitful states because of excellent soil which produces plentiful harvests. I hope to harvest at least [illegible] mud [ 1 mud equals 3 bushels] from 40 acres of wheat and from 60 acres of oats 1,200 mud $[3,600$ bushels]. At present market prices, I can make $\$ 750$ for wheat, $\$ 600$ for oats, and between $\$ 200$ and $\$ 250$ for mustard seed. We calculate that each half morgan [one acre] produces $\$ 10$ worth of products.

For two years I and my family worked all this land, but this year I have someone who helps me. Farming here is entirely different than in Holland; whatever can possibly be done by machine is done by machine. Wheat, oats, hay, also mustard seed is all harvested by machines. I have one myself which cost $\$ 160$ and with which a young man, one man and 4 horses, regularly reap 6 to 8 morgen [ 13 to 17 acres] daily. I expect to purchase a threshing machine in the fall, with which we can thresh 120 to 150 mud [ 360 to 450 bushels] a day.

These reports are from a letter written by a colonist, a former neighbor of the respected Professor (J. Ackersdijck) at Utrecht upon whose veracity we can completely rely. We see from this what a person, relying completely upon his own resources and not expecting help from the government, can accomplish in a new land through diligence and thrift. We also have in our colonies in Pella and Michigan several times as much virgin land as the land area of our country [the Netherlands] and the soil is more fertile. - The Editor 
Copyright of Annals of Iowa is the property of State of Iowa, by \& through the State Historical Society of Iowa and its content may not be copied or emailed to multiple sites or posted to a listserv without the copyright holder's express written permission. However, users may print, download, or email articles for individual use. 